\title{
Treatment of haemorrhage after castration by laparoscopic ligation of the spermatic cord in two horses
}

\author{
Astrid B.M. Rijkenhuizen \\ Universität Utrecht
}

\begin{abstract}
Summary
Post-operative haemorrhage is a life-threatening complication of castrations in stallions. It is considered as one of the most frequent complications. Bleeding from the testicular artery may be caused by insufficient crushing and/or ligation of the artery, or by loosening of the ligature. The bleeding artery may be approached through the scrotal wound, or through an incision at the level of the external inguinal ring. However, sometimes the spermatic cord has retracted into the abdomen which may make localisation of the spermatic stump rather difficult and requires general anesthesia. General anaesthesia is not without risk in these patients as their cardiovascular status may be severly compromised by heavy blood loss. In recent years laparoscopy has been successfully introduced for many indications in equine surgery. Laparoscopic procedures can be carried out in the standing, sedated and locally anaesthetised horse, without necessity for general anaesthesia. In this paper two cases are presented in which laparoscopic techniques were used for the treatment of post-operative haemorrhages in two castrated stallions.
\end{abstract}

Keywords: $\quad$ castration, haemorrhage, spermatic cord, complication, laparoscopy

\begin{abstract}
Behandlung von Blutungen nach Kastration durch laparoskopische Ligatur des Samenstranges bei zwei Pferden
Die Kastration des Hengstes zählt in der Pferdemedizin nach wie vor zu den am häufigsten durch Komplikationen erschwerten chirurgischen Eingriffen. Postoperative Blutungen können in diesem Zusammenhang lebensbedrohliche Formen annehmen. Blutungen aus der A. testicularis entstehen meist durch unzureichende Quetschung oder Ligatur der Arterie oder durch Lösung der Samenstrangligatur. Die Blutungsstelle kann entweder durch die Kastrationswunde oder über eine zusätzliche Inzision über dem Inguinalring erreicht werden. Manchmal jedoch hat sich der Samenstrang in die Bauchhöhle zurückgezogen und ist nur nach Laparotomie darzustellen, was eine Allgemeinanästhesie erforderlich macht. Diese ist gerade bei Patienten mit starkem Blutverlust wegen des kritischen Kreislaufzustandes oft mit Risiko behaftet. In den letzten Jahren wurde die Laparoskopie für zahlreiche Indikationen erfolgreich in die Pferdechirurgie eingeführt. Sie erlaubt nach Sedierung und Lokalanästhesie der Patienten Eingriffe am stehenden Pferd. Die Autorin stellt zwei Fälle vor, in denen die Laparoskopie zur Behandlung von postoperativen Blutungen bei zwei kastrierten Hengsten Anwendung fand.
\end{abstract}

Schlüsselwörter: Kastration, Blutung, Samenstrang, Komplikation, Laparoskopie

\section{Introduction}

Post-operative haemorrhage is a life-threatening complication of castrations in stallions. It is considered as one of the most frequent complications with an incidence of 2.4-3.9\% (Molle et al. 1995, Keller and Hartman 1996). Post-operative haemorrhage can occur immediately after surgery until 5 days later (Nickels 1998, Keller and Hartman 1996). The bleeding may originate from a vessel in the tunica dartos or scrotal fascia, or from the testicular artery. Bleedings from the tunica dartos or scrotal fascia usually do not present serious problems as they can easily be resolved by either direct compression (manual compression or with a haemostat), or by indirectly packing the scrotum with gauze and/or suturing the scrotal wound (Schumacher 1996, Railton 1999, Searle et al. 1999). However, a bleeding from the testicular artery is a potentially life-threatening condition as it may cause haemorrhagic shock and death (Railton 1999).

Bleeding from the testicular artery may be caused by insufficient crushing and/or ligation of the artery, or by loosening of the ligature. The condition is treated by searching the bleeding artery, which is then compressed and preferably (re-)ligated (Hunt
1991, Perkins and Frazer 1994, Schumacher 1996, Keller and Hartman 1999). The bleeding artery may be approached through the scrotal wound, or through an incision at the level of the external inguinal ring. However, sometimes the spermatic cord has retracted into the abdomen which may make localisation of the spermatic stump rather difficult. Alternatively, the bleeding can be ligated by laparoscopic approach in dorsal recumbency (Trumble et al 2000). In these cases exploration of the abdomen through the inguinal canal, by a paramedian laparotomy or by a ventral laparoscopic approach general anesthesia is necessary. General anaesthesia is not without risk in these patients as their cardiovascular status may be severly compromised by heavy blood loss.

In recent years laparoscopy has been successfully introduced for many indications in equine surgery. Laparoscopic procedures can be carried out in the standing, sedated and locally anaesthetised horse, without necessity for general anaesthesia. In this paper two cases are presented in which laparoscopic techniques were used for the treatment of post-operative haemorrhages in two castrated stallions. 


\section{Case reports}

\section{Case 1}

A yearling Arabian stallion had been castrated in standing position using the half-closed technique without the application of a ligature. Post-operatively haemorrhage was noted directly after the castration procedure and the scrotum was sutured. Several hours later, haemorrhage still continued and the horse was referred to the Department of Equine Sciences. At presentation the gelding had a pulse rate of 60 beats/min, respiratory rate was 30 breaths/min, and the mucous membranes had a pale appearance. There was a bilateral scrotal swelling with blood clots at the left side. From the left scrotal wound blood was steadily dripping. A mild anaemia was present (PCV $0.24 \mathrm{~L} / \mathrm{L}$ ).

The haemorrhage was thought to originate from the testicular artery and immediate surgical management seemed necessary. Antibiotics (sodium ampicillin', Ampicillinum ${ }^{7} 10 \mathrm{mg} / \mathrm{kg}$ BWT, intravenously) were administered. Then, the horse was restrained in stocks with the tail tied up and sedated with detomidine $^{2}$ (Domosedan $0.1 \mathrm{mg} / 100 \mathrm{~kg}$ BWT intravenously) together with the analgetic buprenorphine ${ }^{3}$ (Temgesic ${ }^{7} 0.06 \mathrm{mg} /$ $100 \mathrm{Kg}$ BWT intravenously). Sedation was maintained with a continuous infusion of detomidine throughout the procedure. After routine preparation for surgery, local infiltration anaesthesia (lidocaine hydrochloride) was provided at the paralumbar sites for the laparoscope and instrument portals as described for castration in the standing position (Rijkenhuizen 1999). Surgery was started on the left side. At inspection a large blood clot appeared to be present that surrounded the vaginal ring and obscured the position of the spermatic stump (fig. 1). The stump was withdrawn from the inguinal ring by gentle traction on the spermatic cord and appeared to be slightly bleeding (fig. 2). The stump was grasped with a forceps and a ligature (polyglactin $910^{4}$, Vicryl ${ }^{7}$ USP2, Ethicon) was applied which stopped the haemorrhage. The ligature was introduced in the abdominal cavity through the instrumental portal using a grasping forceps and was positioned caudolateral to the stump. The ligature was released from the forceps and picked again on the caudomedial side of the stump with the same forceps and retracted extracorporally. A modified Roeders knot was tied extracorpo-

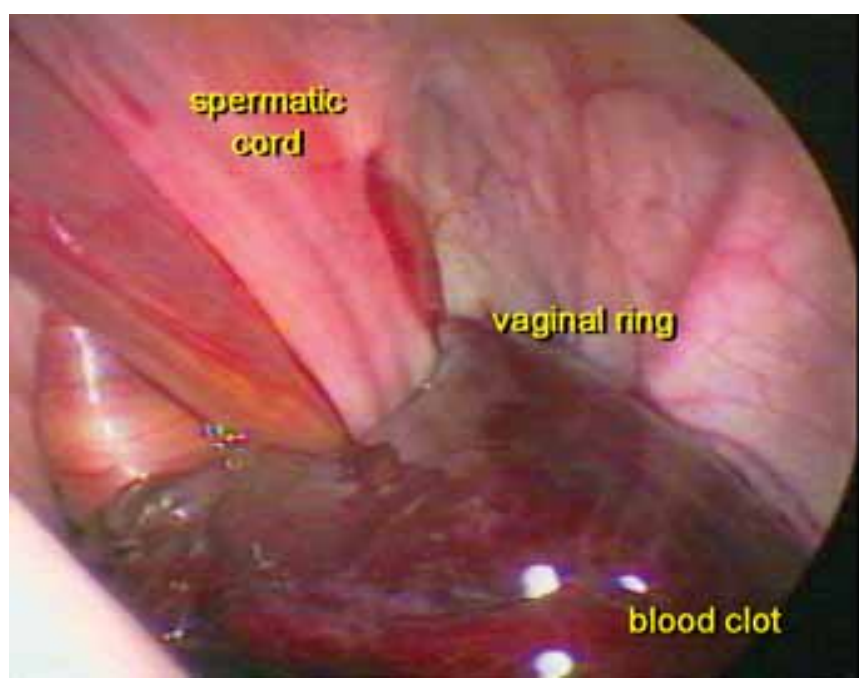

Fig. 1: Laparoscopic view of the left spermatic cord. A blood clot is surrounding the vaginal ring and the spermatic cord.

Laparoscopic view of the left spermatic cord. Ein Blutgerinsel umgibt den Inguinalring und den Samenstrang rally and the slipknot was advanced with a pushrod (Dr. Fritsch ${ }^{7}$, while pulling the long tail of the ligature, and tightened. The suture was cut adjacent to the knot. The laparoscope and instruments were removed, and the skin was closed in routine fashion. The same procedure was performed at the right side. At this side the stump appeared to be free in the abdominal cavity and blood could be seen dripping from the end of the stump. A large blood clot had formed at the site of the vaginal ring. Treatment was identical to the other side. Total surgical time was 65 minutes (skin incision to skin closure).

Post-operatively both scrotal wounds were opened and blood clots removed. Antibiotics (Trimetoprimsulfadiazine ${ }^{5}$, Equitrim ${ }^{\circledR}, 30 \mathrm{mg} / \mathrm{kg}$ twice daily orally) were continued for 3 days. The horse was given walking exercise which started the day after surgery. No further haemorrhage was observed. Swelling of both scrotal wounds had subsided 3 days after surgery. The horse was discharged on the 6th post-operative day and pasture exercise was advised. The owner was contacted by telephone 8 weeks after discharge. Healing had been uneventful and the horse was in good condition.

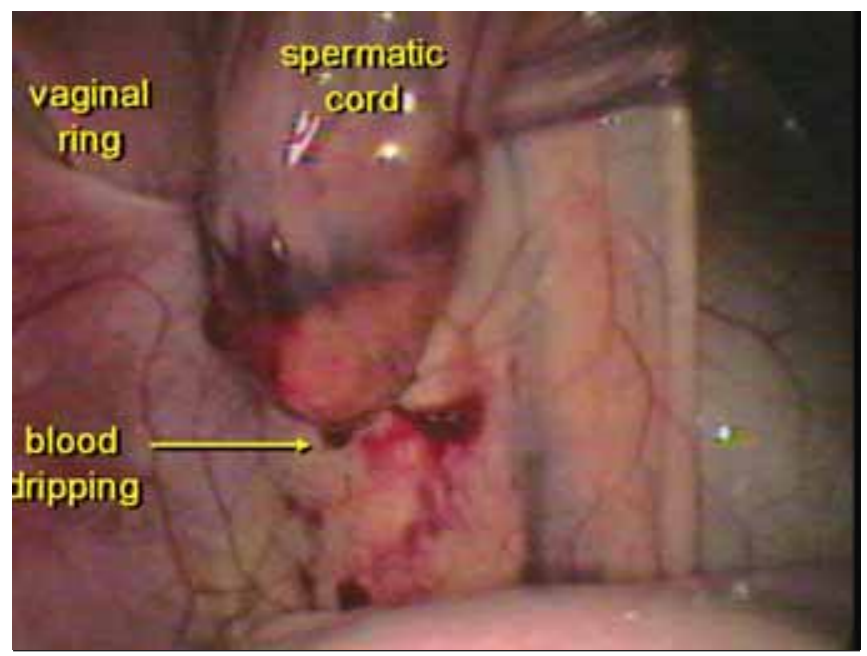

Case 2

A 6-year-old Arabian crossbred stallion had been castrated in the standing position using the half-closed technique. The spermatic cord had been ligated with subsequent transfixation of the ligature. Post-operatively a slight but persistent dripping of blood from the right scrotal wound was noted. The owner decided to contact the practitioner after 3 days. The horse was treated with antibiotics and vitamin $\mathrm{K}$ and referred to the clinic of the Department of Equine Sciences. At presentation the pulse rate was 60 beats/min, respiratory rate was 20 breaths/min, and the mucous membranes were pink with a capillary refill time of less than 2 secs. A mild anaemia (PCV 0.24 L/L) was present. Both scrotal wounds were swollen. Blood was dripping from the right scrotal wound (approximately $1 \mathrm{drop} / \mathrm{sec}$ ), the tail and the hind limbs were covered with blood clots. Further inspection of the scrotal wounds was impossible due to the noncooperative behaviour of the animal.

Prior to surgery sodium ampicilin (Ampicillinum ${ }^{7} 10 \mathrm{mg} / \mathrm{Kg} \mathrm{BWT}$, intravenously) was administered. Preparation for surgery and approach were as in case 1. At laparoscopic inspection a blood 
clot was visible surrounding the vaginal ring on the left side with fresh blood oozing out from the ring into the abdominal cavity. In this case, the spermatic stump was left in position and a ligature (polyglactin 910, Vicryl ${ }^{7}$ USP2, Ethicon) was positioned around the spermatic cord just proximal to the vaginal ring. On the right side the spermatic cord ran through the vaginal ring and thus disappeared from sight. No bleeding or blood clot was visible near this vaginal ring. Here also the stump was left in place and a ligature was positioned around the spermatic cord. Total surgical time was 45 minutes.

After surgery, an attempt was made to remove the blood clots from the scrotal wounds, but this could not completely be achieved due to the fractious nature of the animal. Antibiotics were continued for 3 days (Trimetoprimsulfadiazine, Equitrim ${ }^{\circledR}, 30$ $\mathrm{mg} / \mathrm{kg}$ twice daily orally) and walking exercise was started the day after surgery. There was hardly any swelling of the scrotal wounds. Three days post-operatively the horse was discharged and pasture exercise was advised. Further post-operative recovery was uneventful. Four months after surgery the horse was reported by the owner to be in good condition.

\section{Discussion}

Laparoscopic treatment of post-operative bleeding from the testicular artery was successful in both cases. The affected areas could be easily visualized laparoscopically and identification and subsequent ligation of the spermatic cord presented no problems. Both horses recovered quickly and uneventfully and to the full satisfaction of their owners.
A laparoscopic approach instead of the classical surgical approach in case of post-operative haemorrhages after castration has various advantages. It was considered for uncontrolled bleeding after castration by Trumble et al (2000), but the case described was positioned in dorsal recumbency and in trendelenburg position, which even enhances the risk of general anesthesia (Fahy et al 1996). As stated earlier, there is no need for general anesthesia of these patients which often carry a somewhat higher anaesthetic risk due to the blood loss. Especially the trendelenburg position is known to influence the Further, extensive manipulation of the probably contaminated and possibly infected scrotal and inguinal region is avoided, thus minimizing the risk of contamination of the spermatic cord or even the abdominal cavity. For the same reason, chances of the development of scrotal wound infection and septic funiculitis, which are the two most common complications of the classical approach of post-castration haemorrhages, will be less. Total surgical time will usually not exceed 60 minutes. It should be realized that in the cases described some time was lost because of our status as a veterinary teaching hospital. Disadvantages of the procedure include the need for expensive equipment and a well-skilled laparoscopic surgeon. Further, it should be realized that laparoscopic surgery in animals which have not fasted before surgery carries a higher risk of intestinal perforation. Therefore, it is advisable to start at the left side where the risk of perforation is less. Also, pre-operative rectal exploration during which the intestines are moved away from the puncture site may help in further reducing this risk.

In the first case the spermatic stump was retracted in order to visualize the bleeding end of it. This was not done in the second 
case. In this case the spermatic cord was ligated just proximal to the vaginal ring. In fact, ligation of the spermatic cord without retraction of the stump seems the better procedure as the stump may be infected and should therefore preferably not be retracted into the abdominal cavity. An additional advantage of this location of placing the ligature is that the avascular part of the spermatic cord within the abdominal cavity is as short as possible.

It is concluded that laparoscopic surgery offers excellent possibilities for the treatment of haemorrhages from the testicular artery after castration. Although experiences are limited so far, it seems that the advantages clearly outnumber the disadvantages, making laparoscopy into the method of choice for the treatment of these cases in those clinics where the technique is available.

\author{
Manufacturers' addresses \\ ' sodium ampicillin, Kombivet BV, Etten-Leur, Belgie \\ ${ }^{2}$ detomidine, Pfizer Animal Health BV Capelle aan de lissel, the $\mathrm{Ne}$ - \\ therlands \\ ${ }^{3}$ buprenorphine, Schering-Plough, Maarssen, the Netherlands \\ ${ }^{4}$ polyglactin 910, Ethicon, Somerville, New Jersey, USA \\ ${ }^{5}$ Trimetoprimsulfadiazine, AUV Coöperatie, Cuijk, the Netherlands \\ ${ }^{6}$ Dr. Fritz, Tuttlingen D-78532, Germany
}

\section{Literature}

Fahy B.G., G.M. Barnas, S.E. Nagle, J.L. Flowers, M.J. Nioku and M. Agarwal (1996): Effects of Trendelenburg and reverse Trendelenburg postures on lung and chest wall mechanics. J Clin Anesth 1996; 8, 236-44
Hunt R.J. (1991): Management of complications associated with equine castration. Compend. Contin. Educ. Pract. Vet. 13, 18351841.

Keller H. und U. Hartman (1996): Komplikationsrate verschiedener Kastrationsverfahren bein Hengst. Der praktische Tierarzt. 77; 9, 802817.

Moll H.D., K.D. Pelzer, R.S. Pleasant, P.D. Modransky and K.A. May (1995): A survey of equine castration complications. Equine Vet. Sc.. $12,522-526$.

Nickels F. (1988): Complications of castration and ovariectomy. Vet. Clin.North. Am. (Large Animal Practice), 4, 515-523.

Perkins N.R. and G.S. Frazer (1994): Reproductive emergencies in the stallion. Veterinary clinics of North America: Equine practice. 10, 671-683.

Railton D. (1999): Complications associated with castration in the horse. In practice 298-307.

Schumacher J. (1996): Complications after castration. Equine Vet. Educ.8, 254-259

Searle D., A.J. Dart and D.R. Hodgson (1999): Equine castration: review of anatomy, approaches, techniques and complications in normal, cryptorchid and monorchid horses. Aust. Vet. J. 7, 428-434.

Trumble T.N., J. Ingle-Fehr and D.A. Hendrickson (2000): Laparoscopic intra-abdominal ligation of the testicular artery following castration in a horse. J Am Vet Med Assoc 15, 1596-8.

Astrid B.M.Rijkenhuizen, PhD, Dipl. ECVS., Dipl.RNVA

Department of Equine Sciences

Yalelaan 12

3584 CM Utrecht

The Netherlands

Tel. Nr. 0031-30-2531324

Fax. Nr. 0031-30-2537970

e-mail: a.rijkenhuizen@vet.uu.nl

\section{Buchbesprechung}

\section{Krankheiten der Reitpferde}

P. Launer, J. Mill und W. Richter

2. Auflage, herausgegeben von P. Launer und W. Richter, 1999, E.Ulmer Verlag, Stuttgart, 384 Seiten, 211 Farbfotos, 119 Zeichnungen, 28 Tabellen

\section{Euro}

Die vorliegende 2. Auflage baut auf der bewährten Disposition des Vorgängerwerkes auf. Der Text ist jedoch überarbeitet und auf den aktuellen Stand gebracht. Es werden nicht nur die Erkrankungen abgehandelt, sondern auch Fragen der Entwicklung des Pferdes, seiner artgerechten Haltung und Nutzung sowie die Leistungstähigkeit dargestellt. Es werden aber auch Informationen über die Normwerte des gesunden Tieres, das Verhalten und zum Umgang angeboten. Außerdem gibt es spezielle Hinweise zum Pferdekauf, zur Verfassungsprüfung vor Wettkämpfen und beim Training, zum Doping, zur Alterbestimmung und Identifizierung. Die Beschreibung der Erkrankungen erfolgt nach Organsystemen und Körperregionen. Die Darlegungen sind knapp aber päzise. Weiterhin sind in dem Buch Hinweise zu Vergiffungen, zu Verhaltensstörungen, zum Umgang mit dem erkrankten Pferd und zu Fragen des Tierschutzes zu finden. Eine sehr gute Ausstattung sowie eine ausgezeichnete Bebilderung und auch der Preis zeichnen das Buch weiterhin aus. Es wurde von zwei über Jahrzehnte hinaus erfahrenen Fachtierärzten, welche die Umstände um das erkrankte Pferd genauestens kennen, geschrieben. Aufgrunddessen findet der angesprochenen Interessentenkreis - vordergründig die Pferdehalter und Pferdesportler - auch eine ausreichende Informationsquelle, um rechtbald Abweichungen im Verhalten der von ihnen betreuten Tiere zu erkennen und um schnell tierärztliche Hilfe in Anspruch zu nehmen. Aber nicht nur der Pferdeliebhaber, auch der Student der Veterinärmedizin und auch mancher praktizierende Tierarzt kann in diesem Buch wichtige Hinweise für seine Arbeit finden. Das Buch ist uneingeschränkt zu empfehlen. 